\title{
DATING RECENT PEAT ACCUMULATION IN EUROPEAN OMBROTROPHIC BOGS
}

\author{
Johannes van der Plicht ${ }^{1} \bullet$ Dan Yeloff ${ }^{2}$ Marjolein van der Linden ${ }^{2}$ Bas van Geel ${ }^{2}$ Sally Brain ${ }^{3} \bullet$ \\ Frank M Chambers ${ }^{3} \cdot$ Julia Webb $^{3} \cdot$ Phillip Toms $^{3}$
}

ABSTRACT. This study compares age estimates of recent peat deposits in 10 European ombrotrophic (precipitation-fed) bogs produced using the ${ }^{14} \mathrm{C}$ bomb peak, ${ }^{210} \mathrm{~Pb},{ }^{137} \mathrm{Cs}$, spheroidal carbonaceous particles ( $\mathrm{SCPs}$ ), and pollen. At 3 sites, the results of the different dating methods agree well. In 5 cores, there is a clear discrepancy between the ${ }^{14} \mathrm{C}$ bomb peak and ${ }^{210} \mathrm{~Pb}$ age estimates. In the upper layers of the profiles, the age estimates of ${ }^{14} \mathrm{C}$ and ${ }^{210} \mathrm{~Pb}$ are in agreement. However, with increasing depth, the difference between the age estimates appears to become progressively greater. The evidence from the sites featured in the study suggests that, provided aboveground plant material (seeds, leaves) is selected for dating, the ${ }^{14} \mathrm{C}$ bomb peak is a reliable dating method, and is not significantly affected by the incorporation of old carbon with $10{ }^{14} \mathrm{C}$ content originating from sources including air pollution deposition or methane produced by peat decomposition. ${ }^{210} \mathrm{~Pb}$ age estimates that are too old may be explained by the enrichment of ${ }^{210} \mathrm{~Pb}$ activity in the surface layers of peat resulting from a hypothesized mechanism where rapidly infilling hollows, rich in binding sites, may scavenge ${ }^{210} \mathrm{~Pb}$ associated with dissolved organic matter passing through the hollow, as part of the surface drainage network. Until further research identifies and resolves the cause of the inaccuracy in ${ }^{210} \mathrm{~Pb}$ dating, age estimates of peat samples based only on ${ }^{210} \mathrm{~Pb}$ should be used with caution.

\section{INTRODUCTION}

The increased human impact on the environment and climate during the last few centuries has given added importance to the reconstruction of environmental change during this period. In addition, the overlap between the environmental monitoring programs of the last 50-100 $\mathrm{yr}$ and paleoenvironmental data provides the opportunity to calibrate paleoenvironmental records (Charman and Garnett 2005). The high-precision dating of recent peat deposits has consequently found use in a number of applications, such as linking short-term $(<50 \mathrm{yr})$ ecological monitoring programs with longer-term paleoecological records of 100-200 yr duration for nature conservation (Birks 1996); validating and calibrating peat-based paleoclimate records with instrumental data (e.g. Charman et al. 2004); reconstructions of high-resolution time series of pollutants such as $\mathrm{Hg}$ and $\mathrm{Pb}$ to evaluate the effect of emission controls and calibrate atmospheric transport models (Shotyk et al. 2003); and investigating long-term process of carbon sequestration in peatlands (e.g. Oldfield et al. 1995; Mauquoy et al. 2002).

Holocene peats are most often dated using radiocarbon dating (see Piotrowska et al. 2011). Often, this is the only dating technique applied on a peat profile. Conventionally, ${ }^{14} \mathrm{C}$ dating of near-surface horizons was avoided, for fear of obtaining dates indistinguishable from "modern," and so the ages of these horizons might be estimated by extrapolating to the surface a deposition rate derived from ${ }^{14} \mathrm{C}$ dating of lower peat layers. However, this does not take into account possible changes in peat accumulation rates related to the likely lack of auto-compaction near the surface or, in drained bogs, the countervailing effect of peat shrinkage. Improved dating methods are therefore desirable to improve the accuracy and precision of age estimates of recent peat.

\footnotetext{
${ }^{1}$ Centre for Isotope Research, University of Groningen, Nijenborgh 4, 9747 AG Groningen, the Netherlands; also Faculty of Archaeology, Leiden University, PO Box 9515, 2300 RA Leiden, the Netherlands. Corresponding author. Email: J.van.der.Plicht@rug.nl.

${ }^{2}$ Institute for Biodiversity and Ecosystem Dynamics, Research Group Paleoecology and Landscape Ecology, University of Amsterdam, Science Park 904, 1098 XH Amsterdam, the Netherlands.

${ }^{3}$ Centre for Environmental Change and Quaternary Research, School of Natural and Social Sciences, University of Gloucestershire, Francis Close Hall, Swindon Rd, Cheltenham GL50 4AZ, United Kingdom.
}

(C) 2013 by the Arizona Board of Regents on behalf of the University of Arizona Proceedings of the 21st International Radiocarbon Conference edited by A J T Jull \& C Hatté RADIOCARBON, Vol 55, Nr 2-3, 2013, p 1763-1778 


\section{$J$ van der Plicht et al.}

A number of techniques are available for dating recent peat deposits (see Turetsky et al. 2004 for a review), with each method having advantages and limitations. This paper describes the recent chronology of 10 northern European ombrotrophic peat bogs as part of the EU project ACCROTELM (http://www2.glos.ac.uk/accrotelm/) and the Dutch NWO-ALW program "Climate Change and the Long-Term Dynamics of Bog Ecosystems." The upper layers of peat at each site have been dated using the ${ }^{14} \mathrm{C}$ "bomb peak," ${ }^{210} \mathrm{~Pb}$, and in some cases, stratigraphic markers such as ${ }^{137} \mathrm{Cs}$, spheroidal carbonaceous particles (SCPs), and pollen. This study compares the results of these methods.

\section{DATING TECHNIQUES}

\section{Bomb ${ }^{14} \mathrm{C}$ Dating}

A relatively new method for dating near-surface horizons makes use of the "spike" in ${ }^{14} \mathrm{C}$ concentration related to nuclear weapons testing: so-called bomb ${ }^{14} \mathrm{C}$ dating. Nuclear weapons testing during the 1950 s and early 1960 s approximately doubled the amount of ${ }^{14} \mathrm{C}$ in the atmosphere (e.g. Wild et al. 1998). After the Limited Nuclear Test Ban Treaty of 1963, the ${ }^{14} \mathrm{C}$ concentration of the atmosphere began to decline owing to the exchange of carbon with the ocean and biosphere, and by dilution of atmospheric ${ }^{14} \mathrm{CO}_{2}$ with the burning of ${ }^{14} \mathrm{C}$-free fossil fuels. The biosphere is generally in equilibrium with the atmosphere, and some of this atmospheric ${ }^{14} \mathrm{CO}_{2}$ would have been fixed by terrestrial plants during photosynthesis. The remains of these plants in peat profiles will therefore provide a record of past atmospheric ${ }^{14} \mathrm{C}$ concentration. The large temporal changes in atmospheric ${ }^{14} \mathrm{C}$ concentrations enable the calibration of ${ }^{14} \mathrm{C}$ concentrations in peat deposits against a timescale, and based on direct measurements of atmospheric ${ }^{14} \mathrm{CO}_{2}$ and plant specimens (tree rings and seeds) of known age, there are now several databases of atmospheric ${ }^{14} \mathrm{C}$ concentrations that allow this (e.g. Levin and Kromer 1997). Nevertheless, relatively few studies have used the ${ }^{14} \mathrm{C}$ bomb peak technique to date peats (e.g. Goodsite et al. 2001; Donders et al. 2004; Garnett and Stevenson 2004; Goslar et al. 2005; Sjögren et al. 2006; van der Linden and van Geel 2006; Hua 2009; Piotrowska et al. 2010).

Goslar et al. (2005) observed that any depth increment will likely correspond to more than a single year of peat growth, with an incorporation of ${ }^{14} \mathrm{C}$ activities in the Sphagnum within that increment. This was suggested to lead to a situation where specific dated levels contain a mixture of ${ }^{14} \mathrm{C}$ assimilated over a number of years (integration). An additional source of integration may be $\mathrm{CO}_{2}$ or $\mathrm{CH}_{4}$ produced by the decomposition of older plant tissue (Jungner et al. 1995); and Raghoebarsing et al. (2005) showed experimentally that 5-20\% of the carbon fixed by Sphagnum cuspidatum is the product of symbiotic bacteria oxidizing methane originally derived from decomposing peat. However, this may not affect ${ }^{14} \mathrm{C}$ content significantly in all situations, as Nilsson et al. (2001) found that ${ }^{14} \mathrm{C}$ measurements of living Sphagnum from a variety of mire habitats did not differ from atmospheric levels. Contamination of vegetation by soot particles has also been suggested by Garnett and Stevenson (2004) to dilute the ${ }^{14} \mathrm{C}$ signal in recently accumulated peat, and was shown earlier by Chambers et al. (1979) to yield dates on the fine particulate fraction of peat from South Wales that were thousands of years older than the humic acid fraction. Sphagnum is particularly effective at trapping soot particles (Punning and Alliksaar 1997), and soot is derived from fossil fuel without any ${ }^{14} \mathrm{C}$.

\section{${ }^{210} \mathrm{~Pb}$ Dating}

${ }^{210} \mathrm{~Pb}$ is a naturally occurring isotope of $\mathrm{Pb}$ with a half-life of $22.26 \mathrm{yr}$. The half-life makes it suitable for dating material deposited during the last $150 \mathrm{yr} .{ }^{210} \mathrm{~Pb}$ is produced by the decay of ${ }^{238} \mathrm{U}$ into radon gas $\left({ }^{222} \mathrm{Rn}\right) .{ }^{210} \mathrm{~Pb}$ can accumulate in lacustrine sediments and terrestrial soils. The constant rate of 


\section{Dating Recent Peat in European Ombrotrophic Bogs}

supply (CRS) method has been found to be more applicable for peat deposits, owing to the conditions of organic decay in the aerobic acrotelm (e.g. Appleby et al. 1997).

Laboratory experiments by Vile et al. (1999) showed that $\mathrm{Pb}$ (and therefore ${ }^{210} \mathrm{~Pb}$ ) is immobilized in the peat column by physiochemical binding to organic matter. There is also evidence to suggest that ${ }^{210} \mathrm{~Pb}$-derived dates from ombrotrophic unsaturated peat deposits may be reliable where ${ }^{210} \mathrm{~Pb}$ derived age-depth profiles have been validated by independent evidence such as pollution records, pollen analysis, and other radioisotopes including ${ }^{241} \mathrm{Am}$ (e.g. Appleby et al. 1997; Mackenzie et al. 1998). However, some controversy surrounds the reliability of ${ }^{210} \mathrm{~Pb}$-derived dates from ombrotrophic peat deposits, and there are several studies demonstrating that ${ }^{210} \mathrm{~Pb}$ age estimates are too young (e.g. Oldfield et al. 1979; Urban et al. 1990). Damman (1978) showed that Pb profiles in hummocks and hollows corresponded to the position of the water table on the day of sampling. Damman suggested that $\mathrm{Pb}$ was immobilized as $\mathrm{PbS}$ in waterlogged conditions, and oxidized to soluble $\mathrm{PbSO}_{4}$ when the water table lowered, enabling mobility. Following this, Clymo and Hayward (1982) suggested that the vertical distribution of $\mathrm{Pb}$ (and other heavy metals) is significantly influenced by changes in redox potential resulting from variations in the water table.

\section{${ }^{137}$ Cs Dating}

${ }^{137} \mathrm{Cs}$ is an artificial radionuclide produced by nuclear weapons testing and nuclear power plants (Ritchie et al. 1973). ${ }^{137} \mathrm{Cs}$ chronologies are based on known concentration peaks; atmospheric concentrations have been monitored from 1954 onwards (Appleby et al. 1991), the main example being the 1963 bomb peak. The vertical mobility of ${ }^{137} \mathrm{Cs}$ in ombrotrophic peat deposits of very low mineral content has been demonstrated in a number of studies (e.g. Mitchell et al. 1992; Mackenzie et al. 1997). ${ }^{137} \mathrm{Cs}$ can have both downwards and upwards mobility in the peat column (Schell et al. 1989). Upwards transport occurs as a result of biological activity in the root zone, and saturated and unsaturated conditions at different times of year (Aaby and Jacobsen 1978).

\section{Spheroidal Carbonaceous Particles and Pollen Stratigraphic Markers}

The high-temperature combustion of fossil fuels gives rise to several types of emissions including fine particulate matter, sometimes called fly ash (Rose et al. 1994). These particulates are widely dispersed and deposition usually occurs 5-100 km from the source (Rose and Juggins 1994). Soot particles can be divided into 2 types: 1) spheroidal carbonaceous particles (SCP) with 1-50 $\mu \mathrm{m}$ diameter have a high content of elemental carbon, and their presence in the environment is entirely due to anthropogenic emissions, particularly from oil combustion (Rose 1990a); 2) inorganic ash spheres (IAS) are mainly produced by coal burning, in addition to natural processes such as volcanic eruptions and meteorite impacts (Rose 1990b, 1996), and the small size ( $<20 \mu \mathrm{m}$ diameter) enables long-distance transport in the atmosphere. Techniques such as energy dispersive X-ray analysis (Alliksaar et al. 1998) or the use of different chemical extraction techniques (Rose 1990a,b) can be used to distinguish types of soot particles, and so provide more information for dating. In this study, the different types of soot particles have not been distinguished. If historical records of fossil fuel combustion are available, soot particles can provide a useful stratigraphic marker. However, longdistance transport may complicate the interpretation of the soot particles, as suggested by observations of soot in the Arctic (Rosen et al. 1981).

If historical records of land use are available, then pollen can serve as a useful stratigraphic marker. Problems with the method can arise from postdepositional mobility in the surface layers of peat, which has been demonstrated in the uncompacted surface layers of Sphagnum peat (Rowley and Rowley 1956; Clymo and Mackay 1987). In this study, increases of Pinus and Picea pollen during 
the 19th and 20th centuries around the northern England (GB) and Danish (DK) sites have been dated using local evidence of land use.

\section{METHODS}

The 10 European peat bogs sampled were Butterburn Flow (GB); Lille Vildmose (DK); Männikjärve Bog (ES); Kontolanrahka (FI); Ballyduff Bog (IR); Pedrido Bog (SP); Lappmyran (LPM); Åkerlänna Römosse (ARM); Saxnäs Mosse (SNM); and Fischbruch (FBR). Their locations are shown in Figure 1. The mid-late Holocene ${ }^{14} \mathrm{C}$ chronologies of the ACCROTELM sites GB, DK, ES, and FI have been described in an earlier article (Yeloff et al. 2006). Cores were taken during 2003 from lawns at the deepest "ombrotrophic" zone of each bog, close to the highest point of the mire. Where available, a Wardenaar corer (Wardenaar 1987) was used to remove the top $1 \mathrm{~m}$ of peat. Otherwise, large diameter $(>7 \mathrm{~cm})$ Russian corers were used for sampling. In the laboratory, peat samples were taken at 1-cm depth intervals. The vegetation composition of the peat profiles is reported elsewhere (van der Linden and van Geel 2006; Sillasoo 2007; Mauquoy et al. 2008; van der Linden et al. 2008).

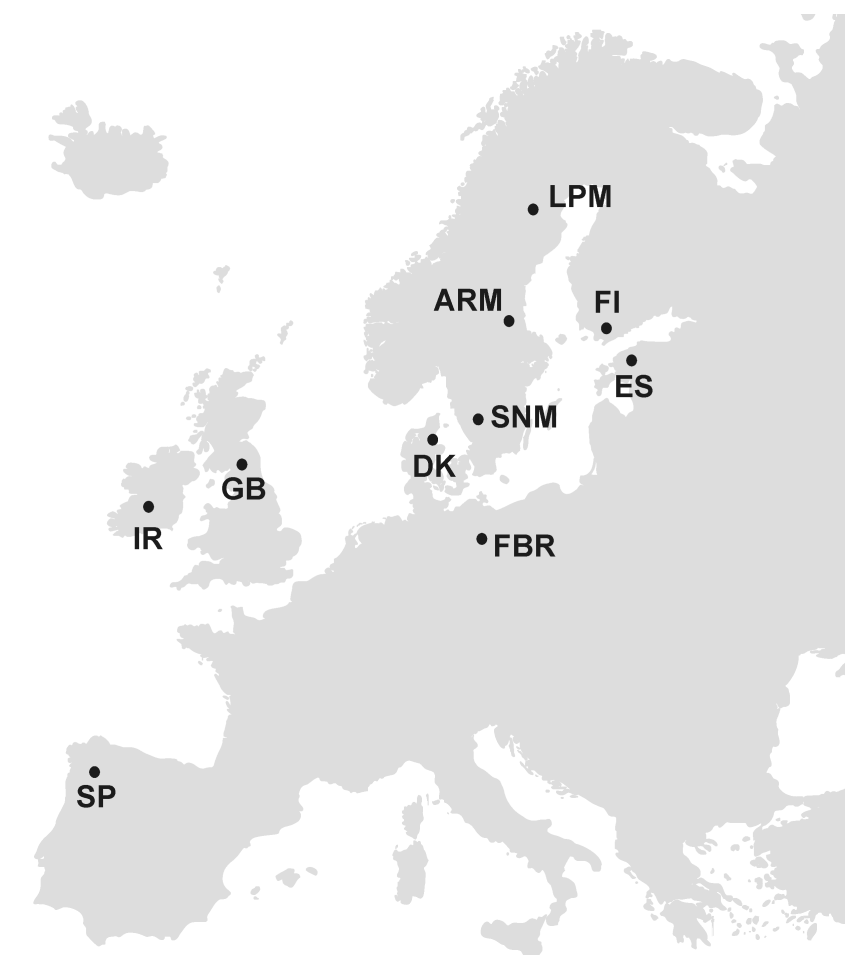

Figure 1 The ombrotrophic peat bogs featured in the study: (GB) Butterburn Flow; (DK) Lille Vildmose; (ES) Männikjärve Bog; (FI) Kontolanrahka; (IR) Ballyduff Bog; (SP) Pedrido; (LPM) Lappmyran; (ARM) Åkerlänna Römosse; (SNM) Saxnäs Mosse; (FBR) Fischbruch.

Selected aboveground plant remains, mainly seeds and Sphagnum stems and branches, were carefully cleaned manually under a stereomicroscope by removing fungal hyphae and other contamination, and pretreated by the AAA method (Mook and Streurman 1983) in order to remove humic acids and recently introduced $\mathrm{CO}_{2}\left(\mathrm{CO}_{2}\right.$ can be potentially absorbed by the sample from the sur- 
rounding air). They were then placed in a petri dish containing some clean (Milli- $\mathrm{Q}^{\mathrm{TM}}$ ) water, checked again under the microscope for contamination, and placed in preweighed tin capsules. After drying at $80^{\circ} \mathrm{C}$ for $72 \mathrm{hr}$, the tin capsules containing the samples were weighed again, closed, and processed further at the Groningen Radiocarbon Laboratory. The tin capsules containing the dried samples were combusted into $\mathrm{CO}_{2}$ and purified using an elemental analyzer (EA) connected to an isotope ratio mass spectrometer (Aerts-Bijma et al. 2001). The EA/MS also enabled the monitoring of quality parameters such as organic carbon content and the $\delta^{13} \mathrm{C}$ value of the sample. The $\mathrm{CO}_{2}$ was then collected cryogenically for graphitization. The graphite powder was pressed into targets that were placed in the sample carousel of the Groningen accelerator mass spectrometer (AMS) ion source. The AMS system measures the isotopic ratios ${ }^{14} \mathrm{C} /{ }^{12} \mathrm{C}$ and ${ }^{13} \mathrm{C} /{ }^{12} \mathrm{C}$ of the graphite (van der Plicht et al. 2000). From these measured isotopic ratios, the ${ }^{14} \mathrm{C}$ activities were calculated (including a correction for isotopic fractionation).

The method for spheroidal carbonaceous particle (SCP) analysis was adapted from Rose (1990a, 1994). Small aliquots of peat $\left(\sim 1 \mathrm{~cm}^{3}\right)$ were first oven-dried at $50{ }^{\circ} \mathrm{C}$. The resulting dried samples $\left(100-400 \mathrm{mg}\right.$ ) were weighed and subsequently digested in $25 \mathrm{~mL}$ of concentrated $\mathrm{HNO}_{3}$ at $180{ }^{\circ} \mathrm{C}$ for $1 \mathrm{hr}$. The remaining residues were washed and decanted into preweighed vials. A small amount of each residue was mounted onto separate microscope slides and individual particles were counted under $400 \times$ magnification. Final weights of the vials and remaining residues were established to permit the calculation of the number of SCPs per gram of dried sediment (ACCROTELM 2006).

Further subsamples of peat were taken from 1-cm intervals throughout the upper $0.5 \mathrm{~m}$ of each core. Each was dried at $50^{\circ} \mathrm{C}$, yielding aliquots of $\sim 0.5 \mathrm{~g}$. These were milled, the $<1-\mathrm{mm}$ fraction separated by sieving, and then compressed and sealed in $10-\mathrm{cc}$ ( $26 \mathrm{~mm}$ diameter) polystyrene pots using polyethylene lids, resulting in negligible gaseous diffusion. Samples were stored for 3 weeks in an attempt to build up and retain ${ }^{222} \mathrm{Rn}$. Measurement of unsupported ${ }^{210} \mathrm{~Pb}$ and anthropogenically generated ${ }^{137} \mathrm{Cs}$ was undertaken by gamma spectrometry using an Ortec GEM-S HPGe coaxial system. The Ge crystal was $71 \mathrm{~mm}$ diameter and $24 \mathrm{~mm}$ thick, contained within an oxygen-free, high-conductivity $\mathrm{Cu}$ cup and endcap and in a vertical cryostat arrangement. The system was shielded using a low-background $\mathrm{Pb}(100 \mathrm{~mm}$ thick, $50-\mathrm{mm}$ undershield $)$ and $\mathrm{Cu}(0.9 \mathrm{~mm}) / \mathrm{Cd}(0.5 \mathrm{~mm})$ lining. Uncertainties are expressed at $1 \sigma$ confidence, reflecting errors combined in quadrature and arising from peak fitting, efficiency calibration, and calculation of unsupported ${ }^{210} \mathrm{~Pb}$ activity.

\section{RESULTS}

The deposition of ${ }^{210} \mathrm{~Pb}$ and ${ }^{137} \mathrm{Cs}$ for the 10 sites is shown in Figure 2. The 1986 Chernobyl event is not clear in the ${ }^{137} \mathrm{Cs}$ profiles at any of the sites, and the 1963 peak in fallout from nuclear weapons is not distinguishable in the ${ }^{137} \mathrm{Cs}$ record of the IR, SP, SNM, and FBR cores. As noted previously, only the GB and DK cores had pollen marker horizons available. SCP horizons were available for the DK and ES sites. Details of the pollen and SCP marker horizons are included in Appendix 1.

Full details of the ${ }^{14} \mathrm{C}$ measurements are presented in Appendix 2, and expressed as $\mathrm{F}^{14} \mathrm{C}$ (the ${ }^{14} \mathrm{C}$ activity ratio after correction for $\delta^{13} \mathrm{C}$, Reimer et al. 2004; van der Plicht and Hogg 2006). Online calibration was conducted using the CALIBomb program (Reimer et al. 2004), using the NH1 data set of Hua and Barbetti (2004), covering the area from $\sim 40^{\circ} \mathrm{N}$ to the North Pole and spanning the period 1955-1999. Calibration of ${ }^{14} \mathrm{C}$ measurements using the bomb peak will always result in multiple (in most cases, double) solutions of age ranges. By assuming that the ${ }^{14} \mathrm{C}$ measurements are in an undisturbed stratigraphic order (shown in Figure 2), with no reworking of older material, it was possible to disregard the age ranges that did not fit with the stratigraphy, and to select the more realistic solution. 


\section{GB Butterburn Flow}

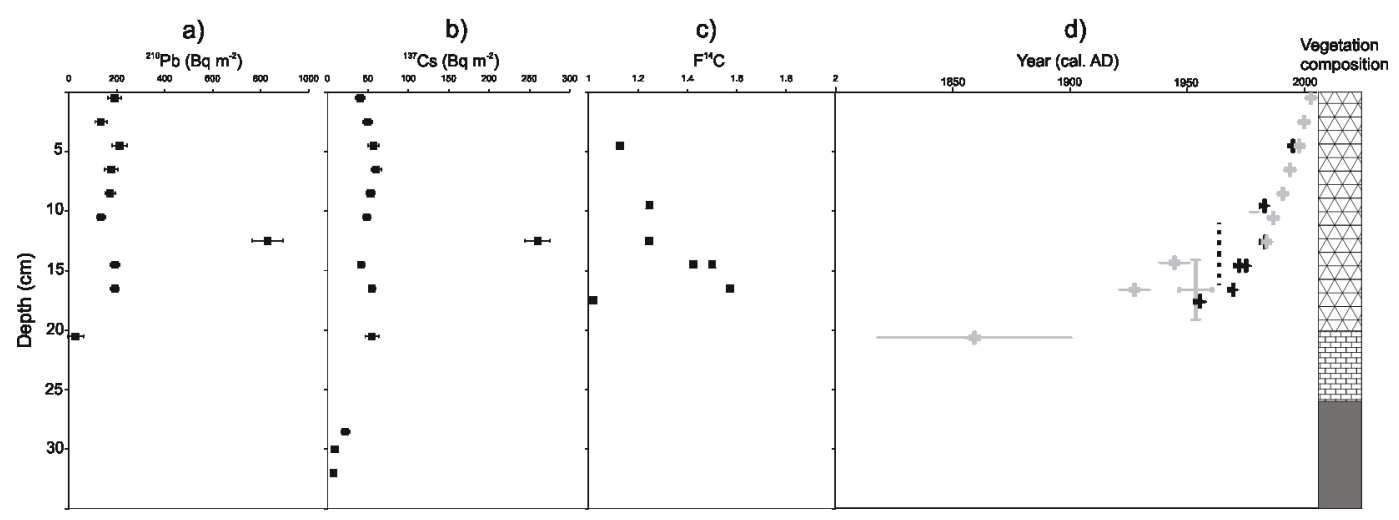

DK Lille Vildmose

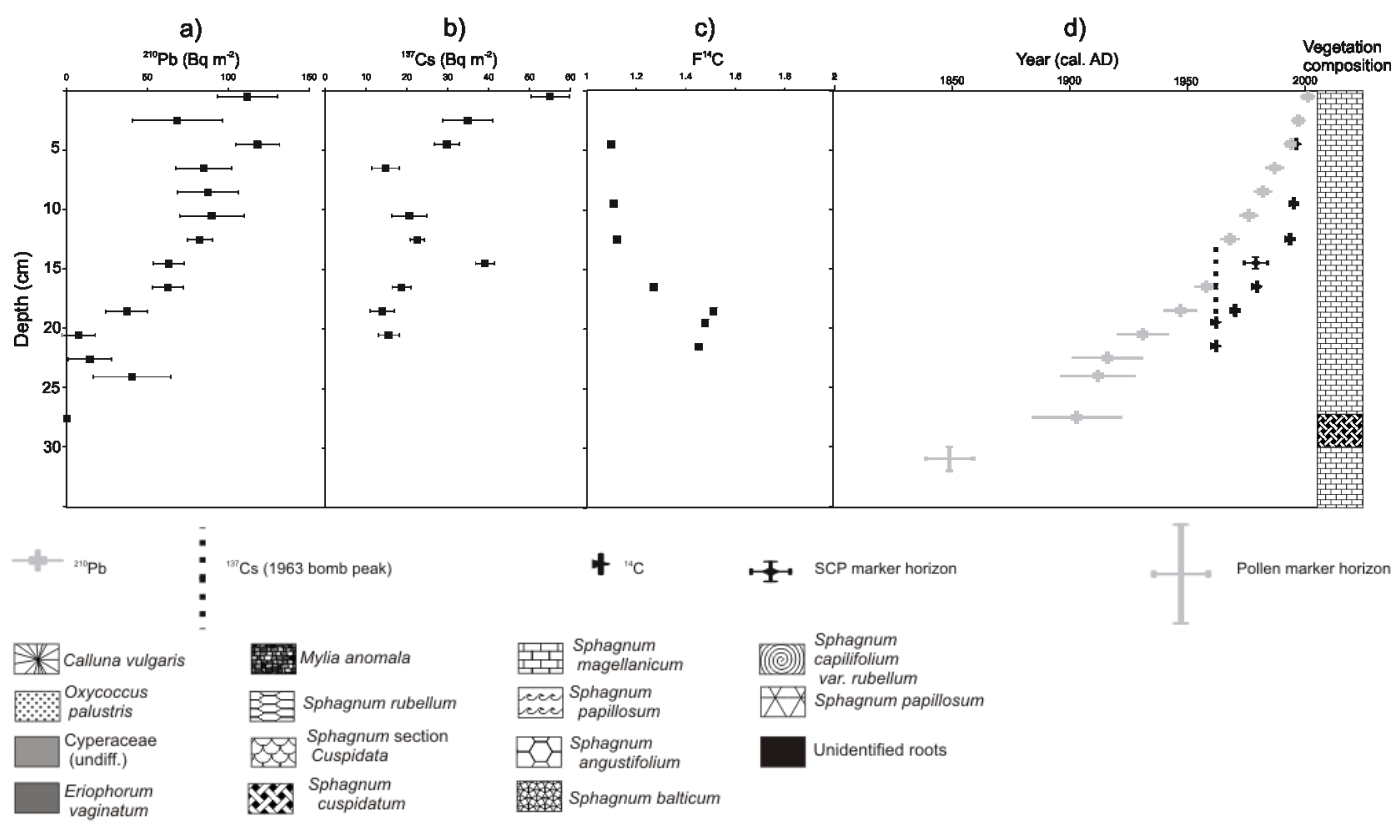

Figure 2 Profiles of ${ }^{210} \mathrm{~Pb},{ }^{137} \mathrm{Cs}$, and ${ }^{14} \mathrm{C}$ shown together with the chronology of recent peat accumulation: a) ${ }^{210} \mathrm{~Pb}$ deposition $\left(\mathrm{Bq} \mathrm{m}{ }^{-2}\right)$; b) ${ }^{137} \mathrm{Cs}$ deposition $\left(\mathrm{Bq} \mathrm{m}^{-2}\right)$; c) $\mathrm{F}^{14} \mathrm{C}$ of plant macrofossils (see Appendix 2 and the text for details); d) agedepth model. Symbols according to the key at the bottom of the diagram. Figure 2-1: Butterburn Flow (GB); Figure 2-2: Lille Vildmose (DK).

Figure 2 shows the results of a) the ${ }^{14} \mathrm{C}$ calibrations and b) age estimates from the different dating techniques used in the study. At 3 sites (GB, ES, and ARM), the results of the different dating methods agree well. At Ballyduff Bog (IR), only the ${ }^{14} \mathrm{C}$ bomb peak and SCP age estimates were available, and the results of these 2 methods appear to agree. In a number of cores (DK, SP, LPM, FBR, and $\mathrm{SNM}$ ), there is a clear discrepancy between the ${ }^{14} \mathrm{C}$ bomb peak and ${ }^{210} \mathrm{~Pb}$ age estimates. In all 


\section{ES Männikjärve Bog}

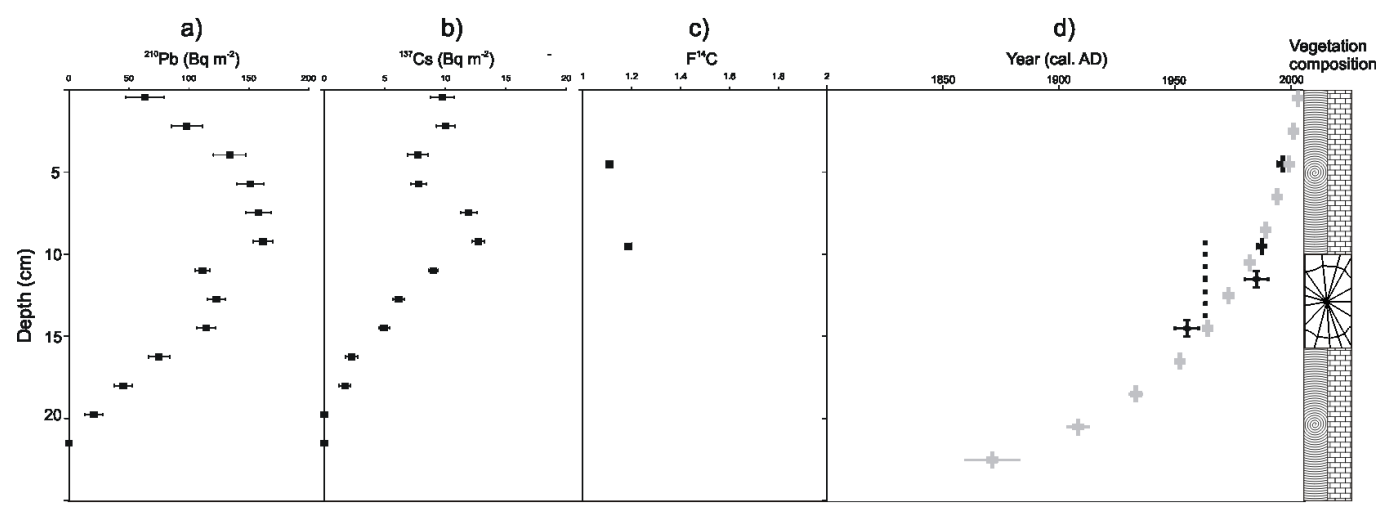

FI Kontolanrahka

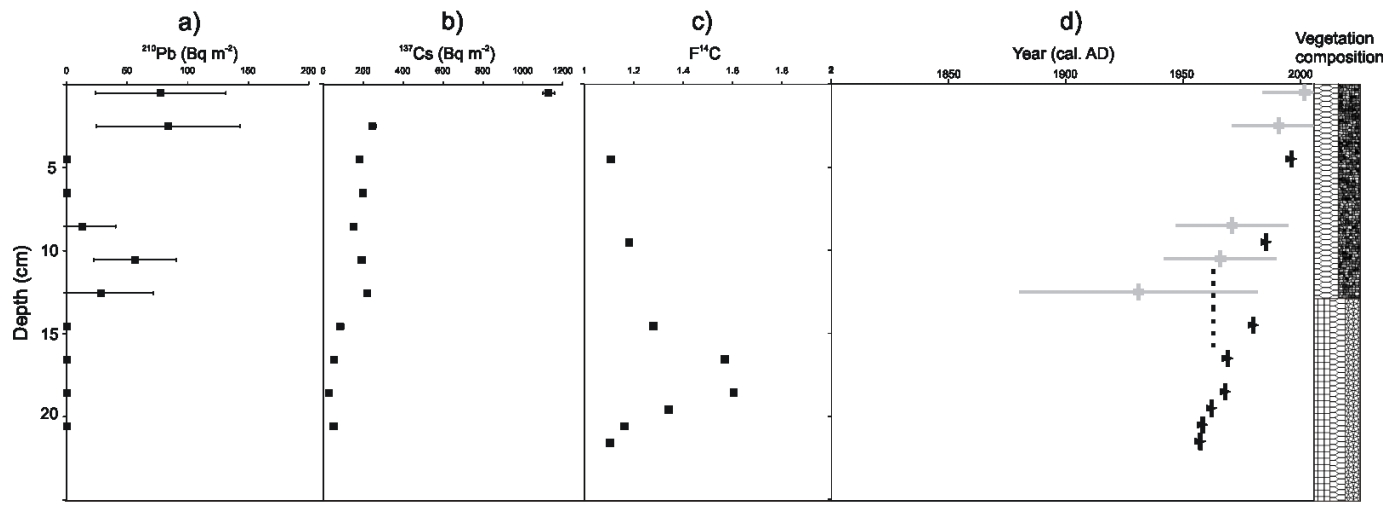

IR Ballyduff Bog

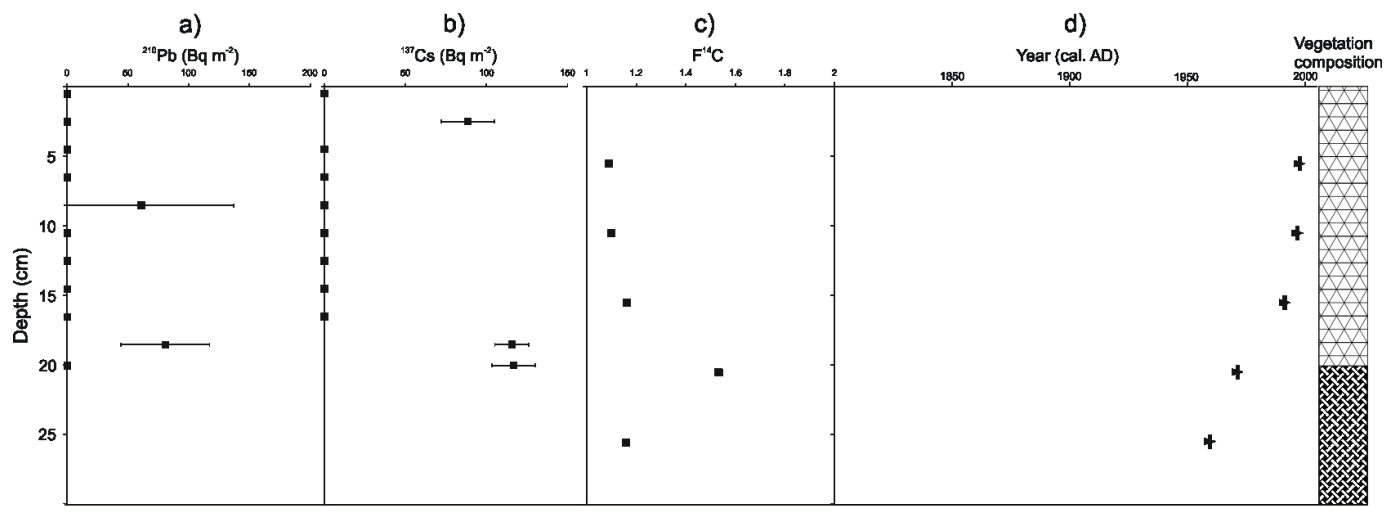

Figure 2-3: Männikjärve Bog (ES); Figure 2-4: Kontolanrahka (FI); Figure 2-5: Ballyduff Bog (IR). 


\section{SP Pedrido}

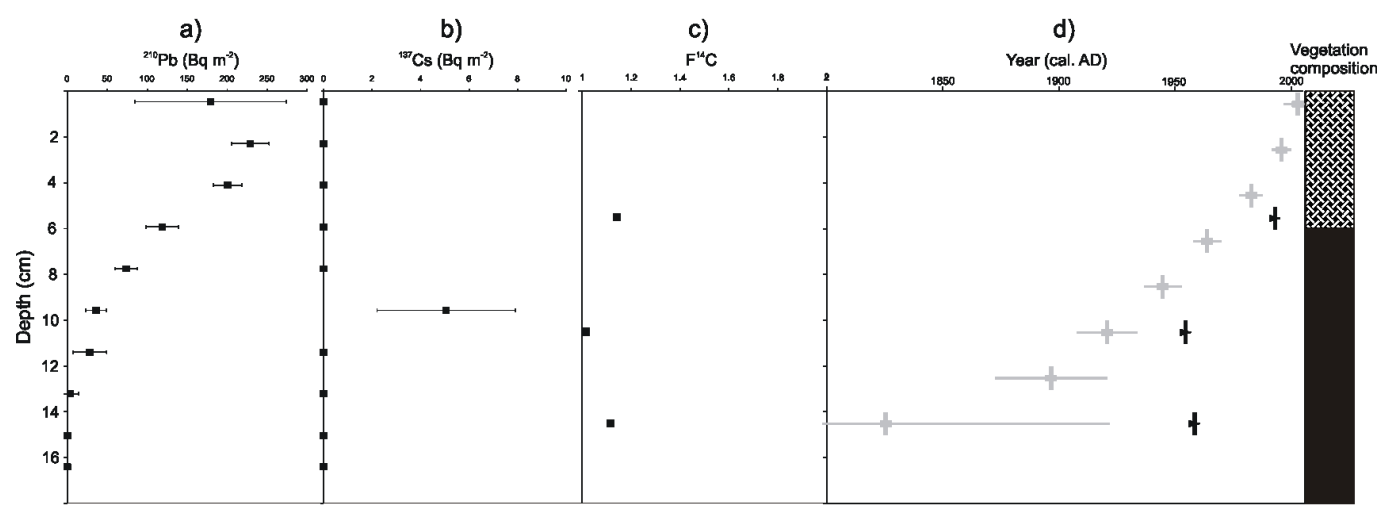

LPM Lappmyran

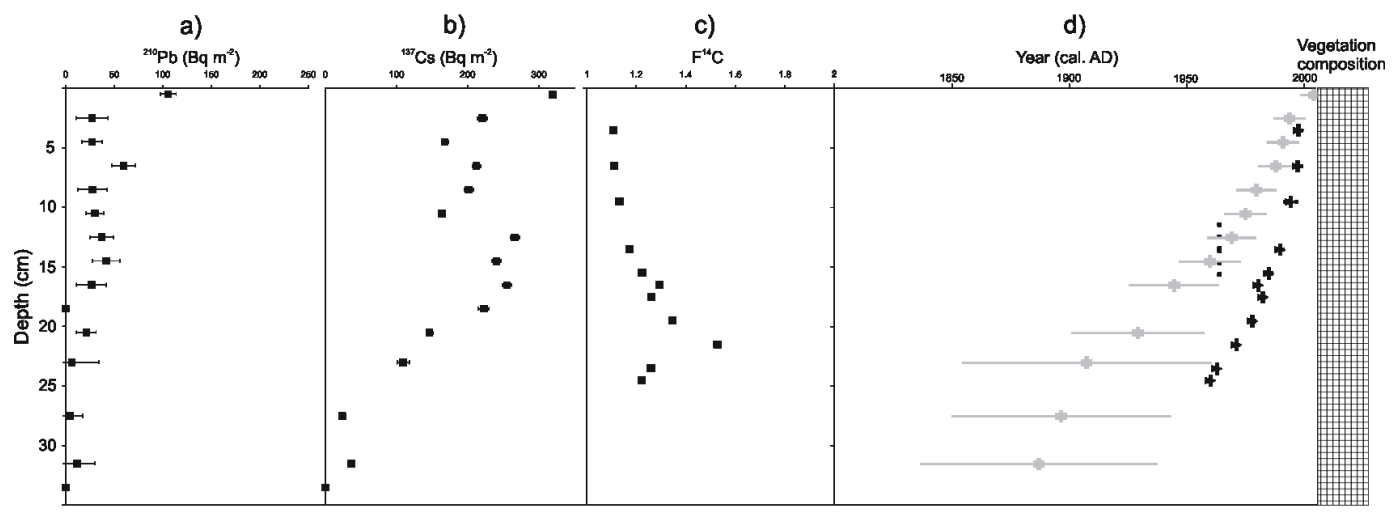

ARM Akerlänna Römosse

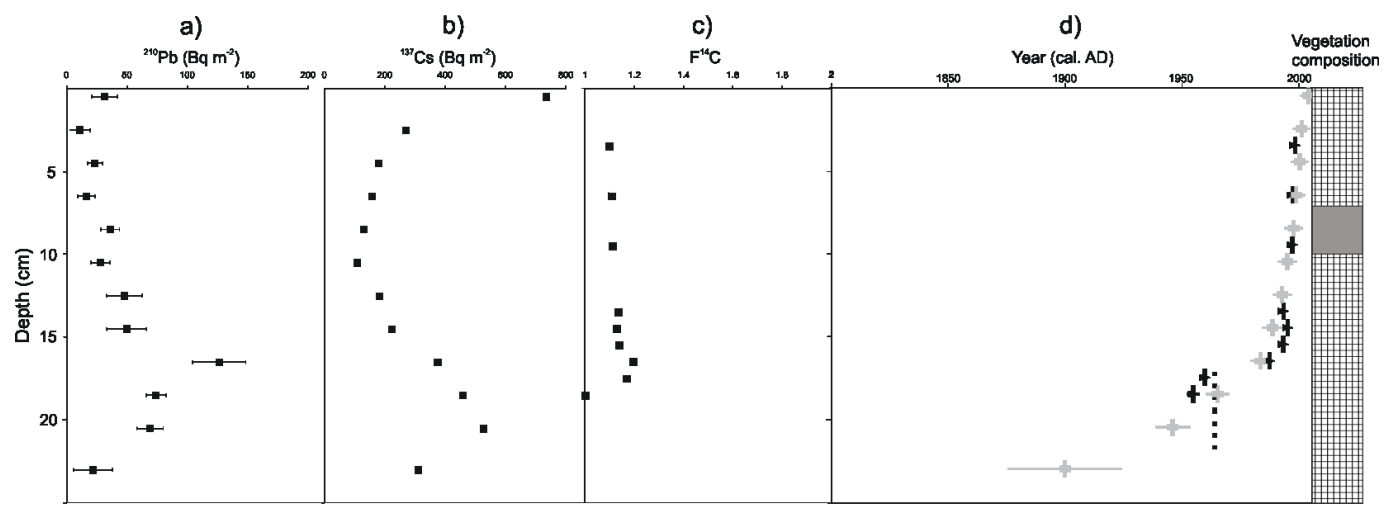

Figure 2-6: Pedrido (SP); Figure 2-7: Lappmyran (LPM); Figure 2-8: Åkerlänna Römosse (ARM) 


\section{SNM Saxnäs Mosse}

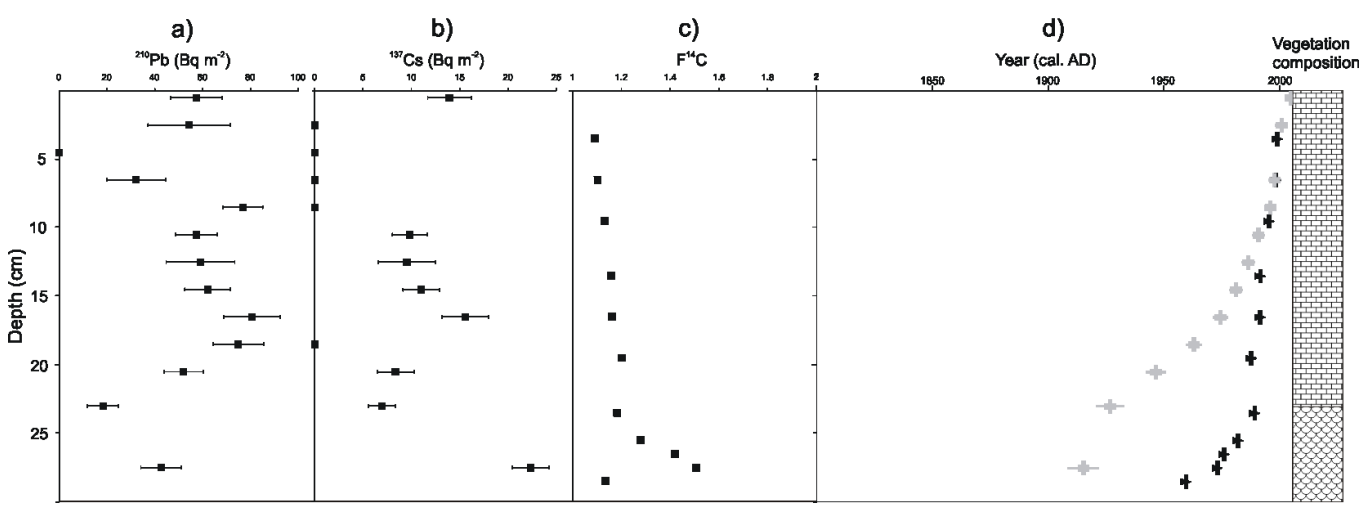

FBR Fischbruch

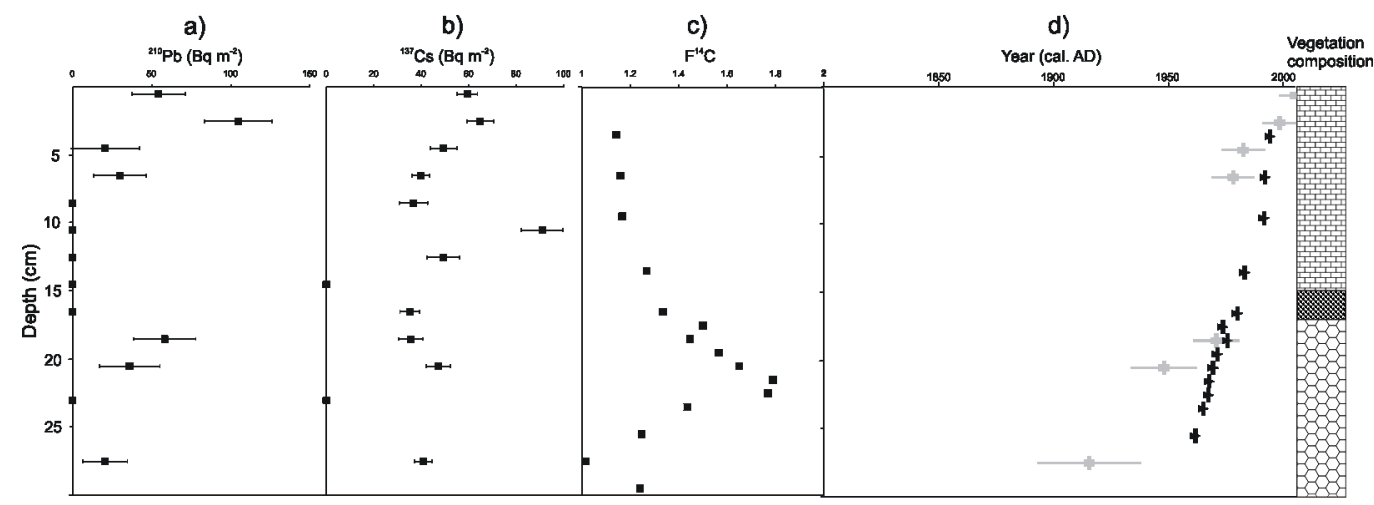

Figure 2-9: Saxnäs Mosse (SNM); Figure 2-10: Fischbruch (FBR)

these cases, the ${ }^{210} \mathrm{~Pb}$ age estimates are older than those based on the ${ }^{14} \mathrm{C}$ bomb peak. In the upper layers of the profiles, the age estimates of ${ }^{14} \mathrm{C}$ and ${ }^{210} \mathrm{~Pb}$ are in agreement. The difference between the age estimates appears to become progressively greater with depth. At the DK and SNM sites, the difference in age estimates between the ${ }^{14} \mathrm{C}$ and ${ }^{210} \mathrm{~Pb}$ methods is as much as $\sim 31 \mathrm{yr}$ and $\sim 65 \mathrm{yr}$ in the lower part of the sequences, respectively.

The ${ }^{137} \mathrm{Cs} 1963$ bomb peak generally agrees with the other dating methods. In the DK and LPM sites, where there is a discrepancy between the ${ }^{210} \mathrm{~Pb}$ and ${ }^{14} \mathrm{C}$ results, the ${ }^{137} \mathrm{Cs} 1963$ peak falls within the distribution of the ${ }^{210} \mathrm{~Pb}$ age estimates.

The relatively few SCP and pollen marker horizons available generally agree with the other dating methods. At the DK site, where there is a discrepancy between the ${ }^{210} \mathrm{~Pb}$ and ${ }^{14} \mathrm{C}$ results, the SCP marker horizon falls within the distribution of the ${ }^{14} \mathrm{C}$ age estimates. 
$J$ van der Plicht et al.

\section{DISCUSSION}

The key issue arising from the results of this study is the discrepancy between ${ }^{210} \mathrm{~Pb}$ and ${ }^{14} \mathrm{C}$ age estimates. The age estimates produced by one (or both) of these methods are prone to significant inaccuracy. Goodsite et al. (2001) also found a discrepancy between ${ }^{210} \mathrm{~Pb}$ and ${ }^{14} \mathrm{C}$ age estimates of peat profiles from Greenland and Denmark, where the ${ }^{14} \mathrm{C}$ dates were much younger than ${ }^{210} \mathrm{~Pb}$ age estimates in the pre-1963 section of the core. In this study, the FI and SP cores also have a few ${ }^{14} \mathrm{C}$ dates before 1963 that are much younger than the ${ }^{210} \mathrm{~Pb}$ age estimates. However, the DK, SP, LPM, FBR, and SNM sites (Figure 2) clearly have numerous ${ }^{14} \mathrm{C}$ dates younger than the ${ }^{210} \mathrm{~Pb}$ age curve, which are above the 1963 bomb peak. Incorporation of older carbon from lower levels in the samples has been proposed by Goslar et al. (2005) to be a cause of problematic ${ }^{14} \mathrm{C}$ age estimates. This phenomenon has also been reported in studies of long-term peat accumulation by Kilian et al. (1995), who reported a reservoir effect in AMS measurements of plant remains from Holocene raised bog deposits, where "older" carbon was proposed to have been incorporated into plant remains through microbial activity. The shift in age estimates resulting from the incorporation of older carbon may be related to the shape of the atmospheric ${ }^{14} \mathrm{C}$ curve. The 1963 peak itself was very rapid and short lived, and ${ }^{14} \mathrm{CO}_{2}$ and ${ }^{14} \mathrm{CH}_{4}$ resulting from the decomposition of the relatively thin layers containing the 1963 peak may not have been consistently incorporated into peat accumulated after 1963. Therefore, the more likely incorporation of older (pre-bomb) carbon into the plant remains could conceivably have resulted in significantly lower ${ }^{14} \mathrm{C}$ content ("dampening"). Based on estimated integration times ranging from 0.7 to $8 \mathrm{yr}$ for peat profiles from a variety of European sites, Goslar et al. (2005) suggested that before and shortly after the 1963 atmospheric peak, integration resulted in dampened ${ }^{14} \mathrm{C}$ values of samples, and a shift towards age estimates that were too old. After 1963, dampened ${ }^{14} \mathrm{C}$ values resulted in age estimates that were too young.

In addition to the fixing of carbon produced by the decomposition of older plant tissue, Charman and Garnett (2005), following Chambers et al. (1979), suggested the dampening of ${ }^{14} \mathrm{C}$ values may result from contamination with the "old" carbon of industrial pollution deposition. Figure 3 shows the spheroidal carbonaceous particle (SCP) concentrations for sites where there is a discrepancy between ${ }^{210} \mathrm{~Pb}$ and ${ }^{14} \mathrm{C}$ age estimates (SCPs were not measured in the LPM and SNM cores). In the DK profile, increased levels of SCPs below $5 \mathrm{~cm}$ depth coincide with the divergence between the ${ }^{14} \mathrm{C}$ and ${ }^{210} \mathrm{~Pb}$ age estimates. The SP site does not show any clear coincidence between soot particle deposition and the divergence between the ${ }^{14} \mathrm{C}$ and ${ }^{210} \mathrm{~Pb}$ age estimates. Also, it must be noted that in the GB core where the results of the different dating methods agree with each other (Figure 3), SCP concentrations reach very high values, with a maximum of about $63 \times 10^{3} \mathrm{~g}^{-1}$.

However, if the incorporation of older carbon does have a significant effect, and ${ }^{210} \mathrm{~Pb}$ age estimates are more accurate, a number of the samples with ${ }^{210} \mathrm{~Pb}$ ages before 1950 (and in some cases in the 19th century) would have an anomalously high ${ }^{14} \mathrm{C}$ content - the source of which is difficult to explain. Furthermore, if the incorporation of older carbon is a significant factor, many of the samples in the layers of peat closest to the surface should have $\mathrm{F}^{14} \mathrm{C}$ values lower than 1 (i.e. a pre-1950 ${ }^{14} \mathrm{C}$ age), but this did not occur at any of the 10 sites featured in this study. This suggests that ${ }^{14} \mathrm{C}$ bomb peak dating is a reliable method, and ${ }^{210} \mathrm{~Pb}$ dating of peat is problematic. ${ }^{210} \mathrm{~Pb}$ dating of peat has been suggested to be unreliable in previous studies, owing to postdepositional mobility - the downward migration of ${ }^{210} \mathrm{~Pb}$ through the peat profile (e.g. Urban et al. 1990). However, downward migration would produce age estimates that are too young (i.e. greater activity at lower levels), and cannot explain the results of this study where ${ }^{210} \mathrm{~Pb}$ age estimates may be too old. Oldfield et al. (1995) hypothesized a mechanism where rapidly infilling hollows, rich in binding sites, may scavenge ${ }^{210} \mathrm{~Pb}$ associated with dissolved organic matter passing through the hollow, as part of the sur- 

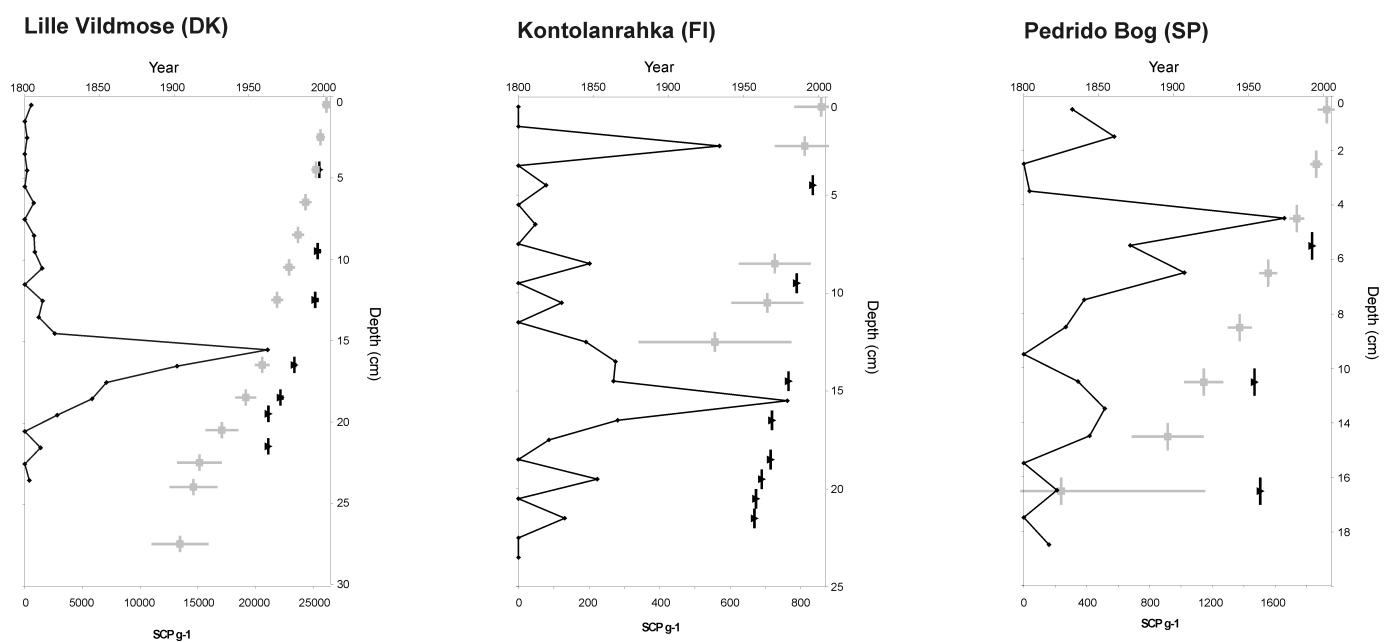

Figure 3 Spheroidal carbonaceous particle (SCP) concentrations (solid black line), ${ }^{210} \mathrm{~Pb}$ and ${ }^{14} \mathrm{C}$ age estimates. Symbols for ${ }^{210} \mathrm{~Pb}$ and ${ }^{14} \mathrm{C}$ age estimates are according to the key in Figure 2.

face drainage network. The enrichment of ${ }^{210} \mathrm{~Pb}$ activity by this mechanism would invariably result in age estimates that are too old. Oldfield et al. cited evidence from excessive ${ }^{210} \mathrm{~Pb}$ inventories of "lawns" at Ellergower Moss, a raised bog in Scotland (Clymo et al. 1990) to support this hypothesis. At the DK and LPM sites, the ${ }^{137} \mathrm{Cs}$ bomb peak falls within the distribution of ${ }^{210} \mathrm{~Pb}$ age estimates, suggesting that ${ }^{137} \mathrm{Cs}$ may also be providing age estimates that are too old.

The mechanism by which the ${ }^{137} \mathrm{Cs}$ profiles were disturbed may be different to that of ${ }^{210} \mathrm{~Pb}$, as studies of ombrotrophic bogs from northern England and Northern Ireland by Oldfield et al. (1979) suggested that the active uptake of ${ }^{137} \mathrm{Cs}$ by living plants on the bog surface was the most likely explanation for the problematic results.

Whatever the reason(s) for the unreliability of the ${ }^{210} \mathrm{~Pb}$ age estimates, it must be related to the occurrence of specific local environmental conditions, as 3 sites out of the 10 featured in this study showed good agreement between the results of the different dating methods. Until further research identifies and resolves the cause of the inaccuracy in ${ }^{210} \mathrm{~Pb}$ dating, age estimates of peat samples based only on ${ }^{210} \mathrm{~Pb}$ should be used with caution.

\section{ACKNOWLEDGMENTS}

Work on Butterburn Flow (GB), Lille Vildmose (DK), Männikjärve Bog (ES), Kontolanrahka (FI), Ballyduff Bog (IR), and Pedrido Bog (SP) constitutes part of the ACCROTELM project ("Abrupt Climate Change Recorded over the European Land Mass"), funded by the European Union 5th Framework program (contract number EVK2-CT-2002-00166); Project members: Jukka Alm, Sue Bartlett, Carole Bégeot, Elizabeth Bingham, Maarten Blaauw, Antony Blundell, Sally Brain, Frank Chambers, Dan Charman, John Daniell, Richard Evershed, John Hunt, Edgar Karofeld, Atte Korhola, Hansjoerg Kuester, Jukka Laine, Michel Magny, Dmitri Mauquoy, Erin McClymont, Fraser Mitchell, Pirita Oksanen, Richard Pancost, Kaarina Sarmaja-Korjonen, Heiki Seppä, Ülle Sillasoo, Bettina Stefanini, Mareike Steffens, Eeva-Stiina Tuittila, Minna Väliranta, Johannes van der Plicht, Bas van Geel, and Dan Yeloff. Work on Lappmyran (LPM), Åkerlänna Römosse (ARM), Saxnäs Mosse (SNM), and Fischbruch (FBR) was funded by the Dutch Organisation of Scientific Research NWO-ALW (grant 852.00.020). 


\section{$J$ van der Plicht et al.}

\section{REFERENCES}

Aaby B, Jacobsen OS. 1978. Changes in biotic conditions and metal deposition in the last millennium as reflected in ombrotrophic peat in Draved Mose, Denmark. Danmarks Geologiske Undersøgelse, Arbog 13: 5-43.

ACCROTELM. 2006. SCP (Spheroidal Carbonaceous Particle) Analysis [WWW document]. URL: http:// www2.glos.ac.uk/accrotelm/SCPproto.html.

Aerts-Bijma AT, van der Plicht J, Meijer HAJ. 2001. Automatic AMS sample combustion and $\mathrm{CO}_{2}$ collection. Radiocarbon 43(2A):293-8.

Alliksaar T, Hörstedt P, Renberg I. 1998. Characteristic fly-ash particles from oil-shale combustion found in lake sediments. Water, Air and Soil Pollution 104(12):149-60.

Appleby PG, Richardson N, Nolan PJ. 1991. ${ }^{241}$ Am dating of lake sediments. Hydrobiologia 214(1):35-42.

Appleby PG, Shotyk W, Fankhauser A. 1997. Lead-210 age dating of three peat cores in the Jura mountains, Switzerland. Water, Air and Soil Pollution 100(3-4): 223-31.

Birks HJB. 1996. Contributions of Quaternary palaeoecology to nature conservation. Journal of Vegetation Science 7(1):89-98.

Chambers FM, Dresser PQ, Smith AG. 1979. Radiocarbon dating evidence on the impact of atmospheric pollution on upland peats. Nature 282(5741):829-31.

Charman DJ, Garnett MH. 2005. Chronologies for recent peat deposits using wiggle-matched radiocarbon ages: problems with old carbon contamination. Radiocarbon 47(1):135-45.

Charman DJ, Brown AD, Hendon D, Karofeld E. 2004. Testing the relationship between Holocene peatland palaeoclimate reconstructions and instrumental data at two European sites. Quaternary Science Reviews 23(1-2):137-43.

Clymo RS, Hayward PM. 1982. The ecology of Sphagnum. In: Gore AJP, editor. Mires: Swamp, Bog, Fen and Moor, Ecosystems of the World. Volume 4A. London: Chapman and Hall. p 229-89.

Clymo RS, Mackay D. 1987. Upwash and downwash of pollen and spores in the unsaturated surface layer of Sphagnum-dominated peat. New Phytologist 105(1): 175-83.

Clymo RS, Oldfield F, Appleby PG, Pearson GW, Ratnessar P, Richardson N. 1990. The record of atmospheric deposition on a rain-dependent peatland. Philosophical Transactions of the Royal Society of London B 327(1240):331-8.

Damman AWH. 1978. Distribution and movement of elements in ombrotrophic peat bogs. Oikos 30(3):48095.

Donders TH, Wagner F, van der Borg K, de Jong AFM, Visscher H. 2004. A novel approach for developing high-resolution sub-fossil peat chronologies with ${ }^{14} \mathrm{C}$ dating. Radiocarbon 46(1):455-63.
Garnett MH, Stevenson AC. 2004. Testing the use of bomb radiocarbon to date the surface layers of blanket peat. Radiocarbon 46(2):841-51.

Goodsite ME, Rom W, Heinemeier J, Lange T, Ooi S, Appleby PG, Shotyk W, van der Knaap WO, Lohse C, Hansen TS. 2001. High-resolution AMS ${ }^{14} \mathrm{C}$ dating of post-bomb peat archives of atmospheric pollutants. Radiocarbon 43(2B):495-515.

Goslar T, van der Knaap WO, Hicks S, Andri M, Czernik J, Goslar E, Räsänen S, Hyötylä H. 2005. Radiocarbon dating of modern peat profiles: pre- and post-bomb ${ }^{14} \mathrm{C}$ variations in the construction of age-depth models. Radiocarbon 47(1):115-34.

Hua Q. 2009. Radiocarbon: a chronological tool for the recent past. Quaternary Geochronology 4(5):378-90.

Hua Q, Barbetti M. 2004. Review of tropospheric bomb ${ }^{14} \mathrm{C}$ data for carbon cycle modeling and age calibration purposes. Radiocarbon 46(3):1273-98.

Jungner H, Sonninen E, Possnert G, Tolonen K. 1995. Use of bomb-produced ${ }^{14} \mathrm{C}$ to evaluate the amount of $\mathrm{CO}_{2}$ emanating from two peat bogs in Finland. Radiocarbon 37(2):567-73.

Kilian MR, van der Plicht J, van Geel B. 1995. Dating raised bogs: new aspects of ${ }^{14} \mathrm{C}$ AMS wiggle-matching, a reservoir effect and climatic change. Quaternary Science Reviews 14:959-66.

Levin I, Kromer B. 1997. Twenty years of atmospheric ${ }^{14} \mathrm{CO}_{2}$ observations at Schauinsland station, Germany. Radiocarbon 39(2):205-18.

MacKenzie AB, Farmer JG, Sugden CL. 1997. Isotopic evidence of the relative retention and mobility of lead and radiocaesium in Scottish ombrotrophic peats. Science of the Total Environment 203(2):115-27.

MacKenzie AB, Logan EM, Cook GT, Pulford ID. 1998. Distributions, inventories and isotopic composition of lead in ${ }^{210} \mathrm{~Pb}$-dated peat cores from contrasting biogeochemical environments: implications for lead mobility. Science of the Total Environment 223(1):25-35.

Mauquoy D, Engelkes T, Groot MHM, Markesteijn F, Oudejans MG, van der Plicht J, van Geel B. 2002. High-resolution records of late Holocene climate change and carbon accumulation in two north-west European ombrotrophic peat bogs. Palaeogeography, Palaeoclimatology, Palaeoecology 186(3-4):275310.

Mauquoy D, Yeloff DE, van Geel B, Charman D, Blundell A. 2008. Two decadally-resolved records from northwest European peat bogs show rapid climate changes associated with solar variability during the mid-late Holocene. Journal of Quaternary Science 23(8):745-63.

Mitchell PI, Schell WR, McGarry A, Ryan TP, SanchezCabeza JA, Vidal-Quadras A. 1992. Studies of the vertical distribution of ${ }^{134} \mathrm{Cs},{ }^{137} \mathrm{Cs},{ }^{238} \mathrm{Pu},{ }^{239,240} \mathrm{Pu}$, ${ }^{241} \mathrm{Pu},{ }^{241} \mathrm{Am}$ and ${ }^{210} \mathrm{~Pb}$ in ombrogenous mires at midlatitudes. Journal of Radioanalytical and Nuclear 


\section{Dating Recent Peat in European Ombrotrophic Bogs}

Chemistry 156:361-87.

Mook WG, Streurman HJ. 1983. Physical and chemical aspects of radiocarbon dating. PACT 8:31-55.

Nilsson M, Klarqvist M, Bohlin E, Possnert G. 2001. Variation in ${ }^{14} \mathrm{C}$ age of macrofossils and different fractions of minute peat samples dated by AMS. The Holocene 11(5):579-86.

Nõges T, Heinsalu A, Alliksaar T, Nõges P. 2006. Paleolimnological assessment of eutrophication history of large transboundary Lake Peipsi, Estonia/Russia. Verhandlungen der Internationalen Vereinigung für Theoretische und Angewandte Limnologie 29(3):1135-8.

Odgaard BV. 1993. The sedimentary record of spheroidal carbonaceous fly-ash particles in shallow Danish lakes. Journal of Paleolimnology 8(3):171-87.

Oldfield F, Appleby PG, Cambray RS, Eakins JD, Barber KE, Battarbee RW, Pearson GW, Williams JM. 1979. ${ }^{210} \mathrm{~Pb},{ }^{137} \mathrm{Cs},{ }^{239} \mathrm{Pu}$ profiles in ombrotrophic peat. $\mathrm{Oi}$ kos 33(1):40-5.

Oldfield F, Richardson N, Appleby PG. 1995. Radiometric dating $\left({ }^{210} \mathrm{~Pb},{ }^{137} \mathrm{Cs},{ }^{241} \mathrm{Am}\right)$ of recent ombrotrophic peat accumulation and evidence for changes in mass balance. The Holocene 5(2):141-8.

Piotrowska N, De Vleeschouwer F, Sikorski J, Pawlyta J, Fagel N, Le Roux G, Pazdur A. 2010. Intercomparison of radiocarbon bomb pulse and ${ }^{210} \mathrm{~Pb}$ age models. A study in a peat bog core from North Poland. Nuclear Instruments and Instruments in Physics Research B 268(7-8):1163-6.

Piotrowska N, Blaauw M, Mauquoy D, Chambers FM. 2011. Constructing deposition chronologies for peat deposits using radiocarbon dating. Mires and Peat 7 : $1-14$.

Punning J-M, Alliksaar T. 1997. The trapping of fly-ash particles in the surface layers of Sphagnum-dominated peat. Water, Air and Soil Pollution 94:59-69.

Raghoebarsing AA, Smolders AJP, Schmid, MC, Rijpstra WIC, Wolters-Arts M, Derksen J, Jetten MS, Schouten S, Sinninghe Damsté JS, Lamers LPM, Roelofs JGM, den Camp HJM, Strous M. 2005. Methanotrophic symbionts provide carbon for photosynthesis in peat bogs. Nature 436(7054):1153-6.

Reimer PJ, Brown TA, Reimer RW. 2004. Discussion: reporting and calibration of post-bomb ${ }^{14} \mathrm{C}$ data. Radiocarbon 46(3):1299-304.

Ritchie JC, McHenry JR, Gill AC. 1973. Dating recent reservoir sediments. Limnology and Oceanography 5: 254-63.

Rose NL. 1990a. A method for the extraction of carbonaceous particles from lake sediment. Journal of Paleolimnology 3(1):45-53.

Rose NL. 1990b. A method for the selective removal of inorganic ash particles from lake sediments. Journal of Paleolimnology 4(1):61-7.

Rose NL. 1994. A note on further refinements to a procedure for the extraction of carbonaceous fly-ash particles from lake sediments. Journal of Palaeolimnology 11(2):201-4.
Rose NL. 1996. Inorganic fly-ash spheres as pollution tracers. Environmental Pollution 91(2):245-52.

Rose NL, Juggins S. 1994. A spatial relationship between carbonaceous particles in lake sediments and sulphur deposition. Atmospheric Environment 28(2):177-83.

Rose NL, Juggins S, Watt J, Battarbee R. 1994. Fuel-type characterisation of spheroidal carbonaceous particles using surface chemistry. Ambio 23(4-5):296-9.

Rosen HT, Novakov T, Bodhaine BA. 1981. Soot in the arctic. Atmospheric Environment 15:1371-4.

Rowley JR, Rowley J. 1956. Vertical migration of spherical and aspherical pollen in a Sphagnum bog. Proceedings of the Minnesota Academy of Sciences 24: 29-30.

Schell WR, Tobin MJ, Massey CD. 1989. Evaluation of trace metal deposition history and potential element mobility in selected cores from peat and wetland ecosystems. Science of the Total Environment 87/88:1942.

Shotyk W, Goodsite ME, Roos-Barraclough F, Frei R, Heinemeier J, Asmund G, Lohse C, Hansen TS. 2003. Anthropogenic contributions to atmospheric $\mathrm{Hg}, \mathrm{Pb}$ and As accumulation recorded by peat cores from southern Greenland and Denmark dated using the ${ }^{14} \mathrm{C}$ "bomb pulse curve." Geochimica et Cosmochimica Acta 67(21):3991-4011.

Sillasoo U, Mauquoy D, Blundell A, Charman D, Blaauw M, Daniell JRG, Toms P, Newberry J, Chambers FM, Karofeld E. 2007. Peat multi-proxy data from Männikjärve bog as indicators of Late Holocene climate changes in Estonia. Boreas 36(1):20-37.

Sjögren P, van Leeuwen JFN, van der Knaap WO, van der Borg K. 2006. The effect of climate variability on pollen productivity, AD 1975-2000, recorded in a Sphagnum peat hummock. The Holocene 16(2):277-86.

Turetsky MR, Manning SWR, Wieder RK. 2004. Dating recent peat deposits. Wetlands 24(2):324-56.

Urban N, Eisenreich SJ, Grigal DF, Schurr KT. 1990. Mobility and diagenesis of $\mathrm{Pb}$ and $\mathrm{Pb}-210$ in peat. Geochimica et Cosmochimica Acta 54(12):3329-46.

van der Linden M, van Geel B. 2006. Late Holocene climate change and human impact recorded in a south Swedish ombrotrophic peat bog. Palaeogeography, Palaeoclimatology, Palaeoecology 240(3-4):649-67.

van der Linden M, Barke J, Vickery E, Charman D, van Geel B. 2008. Late Holocene human impact and climate change recorded in a North Swedish peat deposit. Palaeogeography, Palaeoclimatology, Palaeoecology 258(1-2):1-27.

van der Plicht J, Hogg A. 2006. A note on reporting radiocarbon. Quaternary Geochronology 1(4):236-40.

van der Plicht J, Wijma S, Aerts AT, Pertuisot MH, Meijer HAJ. 2000. Status report: the Groningen AMS facility. Nuclear Instruments and Methods in Physics Research B 172(1-4):58-65.

Vile MA, Wieder RK, Novák M. 1999. Mobility of Pb in Sphagnum-derived peat. Biogeochemistry 45(1):3552. 


\section{$J$ van der Plicht et al.}

Wardenaar ECP. 1987. A new hand tool for cutting peat profiles. Canadian Journal of Botany 65(8):1772-3.

Wild E, Golser R, Hille P, Kutschera W, Priller A, Puchegger S, Rom W, Steier P. 1998. First ${ }^{14} \mathrm{C}$ results from archaeological and forensic studies at the Vienna Environmental Research Accelerator. Radiocarbon 40(1):273-81.

Yeloff DE, Bennett KD, Blaauw M, Mauquoy D, Sillasoo U, van der Plicht J, van Geel B. 2006. High precision ${ }^{14} \mathrm{C}$ dating of Holocene peat deposits: a comparison of Bayesian calibration and wiggle-matching ap- proaches. Quaternary Geochronology 1(3):222-35. Yeloff DE, van Geel B, Broekens P, Bakker J, Mauquoy D. 2007a. Mid- to late-Holocene vegetation and landuse history in the Hadrian's Wall region of northern England: the record from Butterburn Flow. The Holocene 17(4):527-38.

Yeloff DE, Broekens P, Innes J, van Geel B. 2007b. A high-resolution record of vegetation and land-use during the last 1300 years in northeast Jutland (Denmark). Review of Palaeobotany and Palynology 146:182-92.

\section{APPENDICES}

Appendix 1 Pollen and SCP marker horizons. The dates of the SCP horizons are based on histories of local industrial emissions. The pollen markers in both the GB and DK cores are the increases in Picea and Pinus pollen resulting from the documented planting of these trees in the areas of the 2 sites.

\begin{tabular}{llll}
\hline Site & Type of stratigraphic marker (reference) & Depth (cm) & Date (year AD) \\
\hline GB & Pollen (Yeloff et al. 2007a) & $16.5 \pm 2.5$ & $1953 \pm 7$ \\
& SCP (Odgaard 1993) & $14.5 \pm 0.5$ & $1980 \pm 5$ \\
DK & Pollen (Yeloff et al. 2007b) & $31 \pm 1$ & $1850 \pm 10$ \\
ES & SCP (Nõges et al. 2006) & $14.5 \pm 0.5$ & $1955 \pm 5$ \\
& & $11.5 \pm 0.5$ & $1985 \pm 5$ \\
\hline
\end{tabular}

Appendix 2 AMS ${ }^{14} \mathrm{C}$ measurements (expressed as $\mathrm{F}^{14} \mathrm{C}$ ). Calibrated using CALIBomb (Reimer et al. 2004) and the NH1 data set (Hua and Barbetti 2004).

\begin{tabular}{|c|c|c|c|c|c|c|}
\hline $\begin{array}{l}\text { Lab nr } \\
(\mathrm{GrA}-)\end{array}$ & Site & Sample composition & $\begin{array}{l}\text { Mid-point } \\
\text { sample } \\
\text { depth }(\mathrm{cm})\end{array}$ & $\begin{array}{l}{ }^{14} \mathrm{C} \text { activity } \\
\left(\mathrm{F}^{14} \mathrm{C}\right)\end{array}$ & $\begin{array}{l}\delta^{13} \mathrm{C} \\
(\%)\end{array}$ & $\begin{array}{l}\text { Calibrated } \\
\text { age ranges } \\
2 \sigma(y r A D)^{1}\end{array}$ \\
\hline 26623 & ARM & Sphagnum fuscum stems and leaves & 3.5 & $1.0976 \pm 0.0046$ & -27.25 & $1997-1998$ \\
\hline 26624 & ARM & Sphagnum fuscum stems and leaves & 6.5 & $1.1079 \pm 0.0044$ & -27.28 & 1995-1998 \\
\hline 25968 & ARM & Sphagnum fuscum stems and leaves & 9.5 & $1.1116 \pm 0.0062$ & -27.09 & 1995-1998 \\
\hline 26626 & ARM & Sphagnum fuscum stems and leaves & 13.5 & $1.1352 \pm 0.0045$ & -26.97 & 1991-1994 \\
\hline 29024 & ARM & Sphagnum fuscum stems and leaves & 14.5 & $1.1289 \pm 0.0048$ & -27.87 & 1993-1996 \\
\hline 29010 & ARM & Sphagnum fuscum stems and leaves & 15.5 & 1.1405 & -27.05 & 1991-1994 \\
\hline 26627 & ARM & Sphagnum fuscum stems and leaves & 16.5 & 0.0046 & -24.59 & $1985-1988$ \\
\hline 31252 & ARM & Sphagnum fuscum stems and leaves & 17.5 & $1.1697 \pm 0.0036$ & -28.86 & $1958-1959$ \\
\hline 29013 & ARM & Sphagnum fuscum stems and leaves & 18.5 & $1.0027 \pm 0.0044$ & -28.42 & $1951-1957$ \\
\hline 29762 & DK & $\begin{array}{l}\text { Sphagnum magellanicum stems, } \\
\text { leaves and branches }\end{array}$ & 4.5 & $1.0980 \pm 0.0045$ & -28.16 & 1997-1998 \\
\hline 29764 & DK & $\begin{array}{l}\text { Sphagnum magellanicum stems, } \\
\text { leaves and branches }\end{array}$ & 9.5 & $1.1095 \pm 0.0048$ & -31.22 & 1995-1998 \\
\hline 30600 & DK & Sphagnum stems and leaves & 12.5 & 0.0044 & -28.12 & 1993-1996 \\
\hline 30959 & DK & $\begin{array}{l}\text { Sphagnum stems and leaves and Cal- } \\
\text { luna wood }\end{array}$ & 16.5 & $1.2713 \pm 0.0055$ & -27.21 & $1980-1981$ \\
\hline 30989 & DK & Sphagnum stems & 18.5 & 1.511 & -25.92 & 1970-1973 \\
\hline 29757 & DK & Sphagnum stems & 19.5 & $1.4778 \pm 0.0060$ & -22.58 & $\begin{array}{l}1963-1963 ; \\
1972-1973\end{array}$ \\
\hline
\end{tabular}


Appendix 2 AMS ${ }^{14} \mathrm{C}$ measurements (expressed as $\mathrm{F}^{14} \mathrm{C}$ ). Calibrated using CALIBomb (Reimer et al. 2004) and the NH1 data set (Hua and Barbetti 2004). (Continued)

\begin{tabular}{|c|c|c|c|c|c|c|}
\hline $\begin{array}{l}\text { Lab nr } \\
(\text { GrA-) }\end{array}$ & Site & Sample composition & $\begin{array}{l}\text { Mid-point } \\
\text { sample } \\
\text { depth }(\mathrm{cm})\end{array}$ & $\begin{array}{l}{ }^{14} \mathrm{C} \text { activity } \\
\left(\mathrm{F}^{14} \mathrm{C}\right)\end{array}$ & $\begin{array}{l}\delta^{13} \mathrm{C} \\
(\%)\end{array}$ & $\begin{array}{l}\text { Calibrated } \\
\text { age ranges } \\
2 \sigma\left({\text { yr AD })^{1}}^{1}\right.\end{array}$ \\
\hline 30990 & DK & Sphagnum stems & 21.5 & $1.4525 \pm 0.0064$ & -24.67 & $\begin{array}{l}\text { 1963-1963; } \\
1973-1974\end{array}$ \\
\hline 29974 & ES & Sphagnum stems & 4.5 & $1.1074 \pm 0.0044$ & -24.72 & 1995-1998 \\
\hline 29976 & ES & Sphagnum stems & 9.5 & $1.1864 \pm 0.0047$ & -24.56 & 1986-1989 \\
\hline 30497 & FBR & Sphagnum angustifolium stems & 3.5 & $1.1431 \pm 0.0045$ & -28.07 & 1990-1994 \\
\hline 30498 & FBR & Sphagnum angustifolium stems & 6.5 & $1.1598 \pm 0.0046$ & -27.80 & 1989-1991 \\
\hline 26007 & FBR & $\begin{array}{l}\text { Polytrichum strictum stems and } \\
\text { leaves }\end{array}$ & 9.5 & $1.1671 \pm 0.0060$ & -27.27 & 1988-1991 \\
\hline 30500 & FBR & Sphagnum angustifolium stems & 13.5 & $1.2680 \pm 0.0048$ & -27.35 & 1980-1982 \\
\hline 30501 & FBR & Sphagnum angustifolium stems & 16.5 & $1.3341 \pm 0.0051$ & -27.45 & 1977-1979 \\
\hline 30502 & FBR & $\begin{array}{l}\text { Sphagnum angustifolium stems and } \\
\text { Calliergon cordifolium stems and } \\
\text { leaves }\end{array}$ & 17.5 & $1.5002 \pm 0.0056$ & -26.62 & 1971-1972 \\
\hline 30504 & FBR & Sphagnum angustifolium stems & 18.5 & $1.4474 \pm 0.0054$ & -27.66 & 1973-1974 \\
\hline 26008 & FBR & $\begin{array}{l}\text { Sphagnum angustifolium stems, Oxy- } \\
\text { coccus palustris branch with flower, } \\
1 \text { Rhynchospora alba fruit }\end{array}$ & 19.5 & $1.5665 \pm 0.0071$ & -26.47 & $1968-1970$ \\
\hline 30506 & FBR & Sphagnum angustifolium stems & 20.5 & $1.6504 \pm 0.0059$ & -28.63 & $1967-1968$ \\
\hline 30507 & FBR & Sphagnum angustifolium stems & 21.5 & $1.7905 \pm 0.0065$ & -26.16 & $1965-1966$ \\
\hline 30508 & FBR & Sphagnum angustifolium stems & 22.5 & $1.7702 \pm 0.0064$ & -27.43 & $1965-1966$ \\
\hline 30510 & FBR & Sphagnum angustifolium stems & 23.5 & $1.4366 \pm 0.0055$ & -26.81 & $\begin{array}{l}\text { 1963-1963; } \\
1973-1975\end{array}$ \\
\hline 30511 & FBR & Sphagnum angustifolium stems & 25.5 & $1.2472 \pm 0.0048$ & -27.81 & $\begin{array}{l}1959-1960 \\
1981-1983\end{array}$ \\
\hline 29769 & FI & $\begin{array}{l}\text { Sphagnum section Acutifolia stems, } \\
\text { branches and leaves }\end{array}$ & 4.5 & $1.1074 \pm 0.0044$ & -26.88 & 1995-1998 \\
\hline 29768 & FI & $\begin{array}{l}\text { Sphagnum section Acutifolia stems, } \\
\text { branches and leaves }\end{array}$ & 9.5 & $1.1810 \pm 0.0047$ & -25.50 & 1985-1986 \\
\hline 29771 & FI & $\begin{array}{l}\text { Sphagnum section Acutifolia stems, } \\
\text { branches and leaves }\end{array}$ & 14.5 & $1.2791 \pm 0.0049$ & -26.90 & 1979-1981 \\
\hline 30856 & FI & $\begin{array}{l}\text { Sphagnum section Acutifolia stems, } \\
\text { branches and leaves }\end{array}$ & 16.5 & $1.5679 \pm 0.0059$ & -25.42 & $1968-1970$ \\
\hline 31030 & FI & $\begin{array}{l}\text { Sphagnum section Acutifolia stems, } \\
\text { branches and leaves }\end{array}$ & 18.5 & $1.6051 \pm 0.0051$ & -25.95 & 1968-1969 \\
\hline 29772 & FI & $\begin{array}{l}\text { Sphagnum section Acutifolia stems, } \\
\text { branches and leaves }\end{array}$ & 19.5 & $1.3412 \pm 0.0052$ & -24.60 & $\begin{array}{l}1962-1962 \\
1977-1978\end{array}$ \\
\hline 30858 & FI & $\begin{array}{l}\text { Sphagnum section Acutifolia stems, } \\
\text { branches and leaves }\end{array}$ & 20.5 & $1.1617 \pm 0.0046$ & -27.14 & $1958-1959$ \\
\hline 30859 & FI & $\begin{array}{l}\text { Sphagnum section Acutifolia stems, } \\
\text { branches and leaves }\end{array}$ & 21.5 & $1.1046 \pm 0.0044$ & -24.84 & $1957-1958$ \\
\hline 29859 & GB & $\begin{array}{l}\text { Sphagnum papillosum stems, leaves } \\
\text { and branches }\end{array}$ & 4.5 & $1.1272 \pm 0.0054$ & -29.57 & 1993-1996 \\
\hline 29775 & GB & $\begin{array}{l}\text { Sphagnum papillosum stems, leaves } \\
\text { and branches }\end{array}$ & 9.5 & $1.2464 \pm 0.0050$ & -28.19 & $1981-1984$ \\
\hline 30987 & GB & Sphagnum stems and leaves & 12.5 & $1.2450 \pm 0.0059$ & -27.13 & 1981-1984 \\
\hline 29776 & GB & $\begin{array}{l}\text { Sphagnum papillosum stems, leaves } \\
\text { and branches }\end{array}$ & 14.5 & $1.5003 \pm 0.0058$ & -25.86 & 1971-1972 \\
\hline 30792 & GB & Sphagnum stems and leaves & 14.5 & $1.4231 \pm 0.0053$ & -26.29 & $1974-1975$ \\
\hline 30794 & GB & Sphagnum stems and leaves & 16.5 & $1.5731 \pm 0.0059$ & -26.01 & $1968-1970$ \\
\hline 30595 & GB & Sphagnum stems and leaves & 17.5 & $1.0186 \pm 0.0040$ & -25.86 & $1953-1957$ \\
\hline 30140 & IR & $\begin{array}{l}\text { Sphagnum papillosum, Sphagnum } \\
\text { capillifolium stems }\end{array}$ & 5.5 & $1.0897 \pm 0.0046$ & -29.23 & $\begin{array}{l}1996-1996 \\
1957-1958\end{array}$ \\
\hline
\end{tabular}


Appendix 2 AMS ${ }^{14} \mathrm{C}$ measurements (expressed as $\mathrm{F}^{14} \mathrm{C}$ ). Calibrated using CALIBomb (Reimer et al. 2004) and the NH1 data set (Hua and Barbetti 2004). (Continued)

\begin{tabular}{|c|c|c|c|c|c|c|}
\hline $\begin{array}{l}\text { Lab nr } \\
\text { (GrA-) }\end{array}$ & Site & Sample composition & $\begin{array}{l}\text { Mid-point } \\
\text { sample } \\
\text { depth }(\mathrm{cm})\end{array}$ & $\begin{array}{l}{ }^{14} \mathrm{C} \text { activity } \\
\left(\mathrm{F}^{14} \mathrm{C}\right)\end{array}$ & $\begin{array}{l}\delta^{13} \mathrm{C} \\
(\% \circ)\end{array}$ & $\begin{array}{l}\text { Calibrated } \\
\text { age ranges } \\
2 \sigma(\text { yr AD })^{1}\end{array}$ \\
\hline 30142 & IR & $\begin{array}{l}\text { Sphagnum papillosum, Sphagnum } \\
\text { capillifolium leaved stems }\end{array}$ & 10.5 & $1.0981 \pm 0.0044$ & -28.29 & $1995-1995$ \\
\hline 30143 & IR & $\begin{array}{l}\text { Sphagnum papillosum, Sphagnum } \\
\text { cuspidatum, Calluna leaves }\end{array}$ & 15.5 & $1.1619 \pm 0.0049$ & -30.74 & 1989-1991 \\
\hline 30144 & IR & $\begin{array}{l}\text { Sphagnum papillosum, Sphagnum } \\
\text { capillifolium leaved stems }\end{array}$ & 20.5 & $1.5328 \pm 0.0058$ & -26.23 & 1969-1971 \\
\hline 28725 & IR & Sphagnum cuspidatum stems & 25.5 & $1.1595 \pm 0.0046$ & -30.81 & $\begin{array}{l}\text { 1958-1958; } \\
1989-1991\end{array}$ \\
\hline 26368 & LPM & Sphagnum fuscum stems and leaves & 3.5 & $1.1069 \pm 0.0040$ & -29.10 & 1996-1998 \\
\hline 26369 & LPM & Sphagnum fuscum stems and leaves & 6.5 & $1.1115 \pm 0.0040$ & -27.80 & 1995-1998 \\
\hline 25369 & LPM & Sphagnum fuscum stems and leaves & 9.5 & $1.1317 \pm 0.0059$ & -26.97 & 1991-1996 \\
\hline 26371 & LPM & Sphagnum fuscum stems and leaves & 13.5 & $1.1738 \pm 0.0042$ & -28.40 & $1988-1990$ \\
\hline 27755 & LPM & Sphagnum fuscum stems and leaves & 15.5 & $1.2232 \pm 0.0050$ & -27.10 & $1983-1985$ \\
\hline 26372 & LPM & Sphagnum fuscum stems and leaves & 16.5 & $1.2927 \pm 0.0045$ & -26.90 & 1979-1980 \\
\hline 27756 & LPM & Sphagnum fuscum stems and leaves & 17.5 & $1.2598 \pm 0.0051$ & -27.50 & $1981-1982$ \\
\hline 25371 & LPM & Sphagnum fuscum stems and leaves & 19.5 & $1.3454 \pm 0.0068$ & -25.34 & $1976-1978$ \\
\hline 27757 & LPM & Sphagnum fuscum stems and leaves & 21.5 & $1.5275 \pm 0.0061$ & -23.90 & 1970-1971 \\
\hline 26381 & LPM & Sphagnum fuscum stems and leaves & 23.5 & $1.2593 \pm 0.0044$ & -24.90 & $1962-1962$ \\
\hline 27759 & LPM & Sphagnum fuscum stems and leaves & 24.5 & $1.2223 \pm 0.0051$ & -24.00 & 1959-1959 \\
\hline 26501 & SNM & $\begin{array}{l}\text { Sphagnum magellanicum stem and } \\
\text { leaves }\end{array}$ & 3.5 & $1.0927 \pm 0.0054$ & -28.20 & $1997-1998$ \\
\hline 26395 & SNM & $\begin{array}{l}\text { Sphagnum magellanicum stem and } \\
\text { leaves }\end{array}$ & 6.5 & $1.1028 \pm 0.0043$ & -27.10 & 1996-1998 \\
\hline 24430 & SNM & $\begin{array}{l}\text { Sphagnum magellanicum stems and } \\
\text { leaves }\end{array}$ & 9.5 & $1.1299 \pm 0.0060$ & -25.92 & 1992-1996 \\
\hline 27752 & SNM & $\begin{array}{l}\text { Sphagnum magellanicum stems and } \\
\text { leaves }\end{array}$ & 13.5 & $1.1589 \pm 0.0049$ & -25.50 & 1989-1991 \\
\hline 26397 & SNM & $\begin{array}{l}\text { Sphagnum magellanicum stem and } \\
\text { leaves }\end{array}$ & 16.5 & $1.1602 \pm 0.0045$ & -27.20 & 1989-1991 \\
\hline 24431 & SNM & $\begin{array}{l}\text { Sphagnum magellanicum stems and } \\
\text { leaves }\end{array}$ & 19.5 & $1.2016 \pm 0.0074$ & -26.05 & 1984-1988 \\
\hline 26399 & SNM & $\begin{array}{l}\text { Sphagnum magellanicum stem and } \\
\text { leaves }\end{array}$ & 23.5 & $1.1832 \pm 0.0047$ & -26.50 & 1986-1989 \\
\hline 26400 & SNM & Sphagnum stems & 25.5 & $1.2783 \pm 0.0049$ & -26.30 & 1980-1981 \\
\hline 27754 & SNM & $\begin{array}{l}\text { Sphagnum magellanicum stems and } \\
\text { leaves and Sphagnum stems }\end{array}$ & 26.5 & $1.4181 \pm 0.0059$ & -25.80 & 1974-1975 \\
\hline 26621 & SNM & Sphagnum stems and opercula & 27.5 & $1.5058 \pm 0.0056$ & -26.35 & 1971-1972 \\
\hline 27683 & SNM & $\begin{array}{l}\text { Sphagnum stems and Erica tetralix } \\
\text { branch }\end{array}$ & 28.5 & $1.1360 \pm 0.0076$ & -26.40 & $\begin{array}{l}\text { 1958-1958; } \\
1991-1995\end{array}$ \\
\hline 30145 & $\mathrm{SP}$ & $\begin{array}{l}\text { Molinia stems and leaves, Campylo- } \\
\text { pus leaved stems }\end{array}$ & 5.5 & $1.1417 \pm 0.0045$ & -27.73 & 1991-1994 \\
\hline 30383 & $\mathrm{SP}$ & $\begin{array}{l}\text { Eriophorum, Molinia stems, Androm- } \\
\text { eda seeds }\end{array}$ & 10.5 & $1.0161 \pm 0.0059$ & -25.24 & $1952-1956$ \\
\hline 30384 & $\mathrm{SP}$ & $\begin{array}{l}\text { Campylopus, Hypnum, Eriophorum, } \\
\text { Molinia }\end{array}$ & 14.5 & $1.1163 \pm 0.0066$ & -25.81 & $\begin{array}{l}\text { 1957-1958; } \\
1994-1998\end{array}$ \\
\hline
\end{tabular}

